\title{
7
}

\section{MANAGING THE CORONAVIRUS PANDEMIC IN SWITZERLAND}

\section{How federalism went into emergency mode and struggled to get out of it}

\section{Eva Maria Belser?}

\subsection{Introduction}

Switzerland was a federation calmly polishing its aged edifice of powerdividing and -sharing when it was hit by the coronavirus pandemic. What occurred next felt like a hurricane blowing through the country's institutional landscape. In mid-March 2020, three weeks after the first person tested positive for Covid-19, the venerable pillars of Swiss constitutional law - federalism, democracy, the rule of law and human rights - seemed to tremble. The Federal Council declared a state of emergency, and the country underwent a period of centralisation of power such as it had never witnessed before. Parliaments changed into speechless institutions, cantons into mere recipients of orders, and all simply waited for the next press conference by the national executive to find out what rules were to be obeyed and what rights and freedoms were still left. What had happened? Moreover, what are the consequences of a crisis in which federalism was regarded as too complicated, democracy too slow, the rule of law too flexible, and human rights too individualistic to protect public health effectively?

The Swiss coronavirus pandemic story starts at the end of February 2020. When Italy reported its first cases, Switzerland's federal authorities - under the leadership of the Federal Office of Public Health - established a taskforce to carry out an information campaign on health-protection measures. At the same time, cantons started to prepare for the pandemic, with some declaring an emergency situation, others banning large events, and others yet deciding to wait and see. When the first Swiss Covid-19 case was confirmed, the Federal Office of Public Health continued to assess the risk for the general public as moderate and recommended that the 8.6 million Swiss inhabitants regularly wash their hands and sneeze into their elbows. The Swiss population, benefiting from a 
high-performing health system and mandatory social health insurance system, seemed well prepared to face a major health crisis.

However, the country's age demographics - with only 20 per cent of the population younger than 20 years, 61 per cent between 20 and 64 years, and 19 per cent over 65 - would soon prove to be one of the reasons for an increasing fatality rate (Federal Statistical Office n.d.). The high density of the population also posed a challenge to containing the spread of the virus. Only about 15 per cent of the population live in rural areas, while the rest are concentrated in urban areas, such as Zurich, Geneva, Basel, Bern, and Lausanne, or in agglomerations (Federal Statistical Office 2020). In addition, the population's high mobility affected the pandemic and its management: given the small size of the country and its division into 26 cantons, thousands of workers and consumers commute across cantonal borders daily, and even small and medium-sized enterprises operate across borders.

In examining the federal aspects of Switzerland's pandemic management, I argue that federalism did not fail during the pandemic - as numerous actors claimed - but was put in emergency mode as foreseen in the Constitution and the Epidemics Act. Federal structures thus did not hinder prompt and effective pandemic responses but were flexibly adapted to new circumstances: since cantons were unable individually or jointly to act quickly to control a virus indifferent to cantonal borders, concentrating power at the federal level was in line with the principle of subsidiarity. Although it felt like a mighty storm severely disrupting the institutional landscape, the pandemic response putting federalism in emergency mode at first worked to plan.

However, I will show that the country struggled to find its way into a new pandemic normalcy. One of the reasons for this is that since the end of the first wave in June 2020 when the epidemic regime was downgraded from being 'extraordinary' to being 'special', both tiers of government hoped for the other to introduce restrictive measures controlling the pandemic - and to pay for the ameliorative measures softening their effects. The principle of fiscal equivalence - namely that whoever decides, pays - thus seems to generate a negative struggle over competences ('someone else should do it'). Hence, it seems clear that Switzerland should revisit certain aspects of its institutional setup in order to deal better with the federal dynamics that arise during protracted emergencies.

\subsection{The federal constitutional and legislative framework}

As happens in most aggregative federations, the Swiss Federal Constitution enumerates the federal competences while residual powers are vested with the cantons. Cantonal autonomy is extensive and includes institutional, legislative, administrative, and fiscal matters. With the Covid-19 pandemic, the constitutional and legislative framework on epidemics and on emergency rules set the scene for the country's response measures. 


\subsubsection{Constitutional and legislative powers in health matters}

Health, in general, is a cantonal matter. The Confederation, however, has a constitutionally limited mandate to issue legislation in enumerated fields, among them 'the combating of communicable, widespread or particularly dangerous human and animal diseases' (Federal Constitution, article 118, paragraph 2 lit. b). The Federal Act on Epidemics was adopted in 1970 but revised entirely in 2013 to improve the country's preparedness for fast-spreading diseases and to clarify emergency rules (Belser and Mazidi 2020). As the Act also provides a legal basis for introducing compulsory vaccination for specific groups, such as people at risk or particularly exposed in case of a health crisis, opponents of vaccines called for a popular referendum. However, the Swiss population, borne of its experiences with severe acute respiratory syndrome (SARS) and other recent epidemics, approved the law in a popular vote. All measures of the Federal Council preventing or combating the spread of Covid-19 are based on this law and thus cannot be said to lack democratic legitimacy.

The Epidemics Act applies a three-stage model. In 'normal' situations, the federal tier, in consultation with the cantons, determines aims and strategies, but it is up to the cantons to prevent and control diseases (Bergamin and Mazidi 2020: 15-16; Stöckli 2020: 18-19). There is some evidence that the normal situation was not managed appropriately in the recent past (Zeltner 2018: 15-16). Apparently, numerous cantons have not complied with national aims (in particular regarding the stocking of protective materials), preferring to invest financial resources for the health sector in seemingly more urgent matters (such as cancer and dementia); in turn, the federal authorities have failed to use their surveillance powers to insist on observance of the national strategy. The Covid-19 pandemic thus hit a country that was not as prepared as it should have been.

In 'special' situations - in which the country found itself from 28 February to 16 March 2020 and again since 20 June up to the time of writing - the Federal Epidemics Act entrusts the Federal Council with a clearly defined extra set of competences that otherwise would be cantonal matters. The council may ban or limit events, close schools and other public institutions or private enterprises, or restrict their way of operating, prohibit people from accessing or leaving a building or an area, and ban or restrict certain activities within defined zones. However, it may use these special competences only after consulting with the cantons - a rule ensuring, first, that the loss of cantonal autonomy is compensated for by institutional cooperation and, secondly, that the cantonal governments, which are in charge of the health sector and aware of the situation on the ground in the areas under their jurisdiction, contribute appropriately to the making of special rules (Bergamin and Mazidi 2020: N17-20; Kley 2020: 272; Stöckli 2020: 19). During the crisis in 2020, it became clear that the special situation was not sufficiently regulated and that the concurrent competencies, combined with the absence of joint bodies monitoring the disease and coordinating actions, raised the risk of conflicts in competence. 
Finally, when the situation is declared 'extraordinary', the Federal Council may take any necessary measure for the entire country or some parts of it; in such a case, prior consultation with the cantons is no longer mandatory according to the Epidemics Act, albeit still mandated by the Constitution to the extent possible. This situation - in which the country found itself between 17 March and 19 June 2020 - is foreseen but not regulated by law and leaves numerous questions open (Bergamin and Mazidi 2020: N21-22; Stöckli 2020: 19-21). In particular, it is unclear how far the federal competences reach, whether the Federal Council is bound by federal law or may amend it and whether the cantons are allowed to go beyond the federal rules.

\subsubsection{Constitutional and legislative emergency powers}

The Federal Constitution provides the Federal Assembly and Federal Council with emergency powers. 'If extraordinary circumstances require', the parliament may issue ordinances or decrees to safeguard the external and internal security of Switzerland, with these ordinances or decrees exempted from the usual optional referendum that would otherwise delay parliamentary laws from entering into force (Federal Constitution, article 165). In the past and during the Covid-19 crisis, parliamentary emergency powers have not been relevant.

In contrast, the slightly more restrictive executive emergency powers are deployed regularly. The Federal Council can use emergency power in international relations and in case of serious threats to external and internal security (Federal Constitution, articles 184 and 185) and may, in direct application of the Constitution, 'issue ordinances and rulings in order to counter existing or imminent threats of serious disruption to public order or internal or external security' (article 185, paragraph 3). The emergency ordinances must be limited in duration and necessary to protect fundamental legal values such as peace, life, and public health.

In recent times, the Federal Council has used its emergency powers on several occasions. For instance, in 2001 it issued an ordinance prohibiting Al-Qaeda. The ordinance was limited in duration - to two years - but was extended three times before it was finally transposed into an ordinance of Parliament in 2011 and emergency legislation of Parliament in 2014, which itself was later extended. Numerous constitutional scholars claimed that such perpetuation of emergencies violated the Constitution (Biaggini 2017b: N10b; Künzli 2015: N43; Saxer 2014: N108). The Federal Council also used its emergency powers in 2007 and 2008 to order the destruction of plans containing information about atomic bombs. Here, its use of emergency powers was criticised for interfering in the sphere of the judiciary (Biaggini 2017a: N17; Brunner et al. 2020: 688; Saxer 2014: N109-111).

Most famously, the Federal Council made extensive use of its emergency powers during the financial crisis of 2008. The executive adopted a comprehensive programme to support the Swiss finance system and bailed out the private 
bank UBS, arguing that the bank was 'too big to fail'. This case was particularly controversial, as the claimed emergency was of an economic - and private nature and views were deeply divided on whether the bankruptcy of a bank constituted a serious threat to national security (Kley 2011: 133-4). In the notorious UBS case, the Federal Supreme Court supported the view that emergency situations were not limited to serious threats to peace, life, and public health but could result from an economic and social crisis (Federal Court Decision, BGE 137 II 431, paragraph 4.1). Various scholars criticised the judgment, arguing that it opens the doors too widely to emergency powers.

The contentious use of emergency powers led to a number of legislative amendments. In 2011, a Federal Act on the Safeguard of Democracy, Rule of Law and Capacity to Act in Extraordinary Situations entered into force. It obliges the Federal Council to inform parliamentary commissions immediately when it uses emergency powers and states that executive ordinances cease to be effective if they are not submitted to Parliament within six months (Government and Administration Organisation Act, article 7(d), paragraph 2). There is, however, still no agreement on the limits of emergency powers. While most agree that emergency powers do not allow the Federal Council to violate the Constitution, there is an ongoing dispute as to whether they permit the council to break or amend parliamentary laws (Saxer 2014 N101-104; Stöckli 2020: 24-5). The Federal Council based all economic aid and Covid-19 recovery measures on its constitutional emergency powers. It informed parliamentary commissions and, after a few months, submitted the Federal Covid-19 Act to Parliament in compliance with the six-month' deadline.

In sum, two parallel emergency regimes unleashed unprecedented executive powers at the federal level. The Federal Council implemented the Federal Epidemics Act, on which it based all health-related measures and also used the general emergency clause of the Constitution for all economic-support measures.

\subsection{Preparedness for a national disaster: The institutional framework}

As the cantons are competent to deal with health issues, they all have a ministry of health headed by one the members of the collegial cantonal government. The 26 ministers of health are represented in the inter-cantonal conference of cantonal health ministers, a crucial body of horizontal and vertical cooperation. All cantons have cantonal doctors in charge of the test-trace-quarantine-isolate approach and empowered to issue binding orders for individuals. Cantonal health laws provide for emergency rules, mostly by establishing taskforces, as do most security and police laws. When the Covid-19 pandemic struck the country, most cantons thus established special health, security, and coordinating taskforces. Some of them were foreseen by law, others were formed ad hoc. The composition, tasks, and procedures were not always transparent, with the mushrooming of bodies having led to some confusion about who was doing what. 
On the federal level, the Epidemics Act provides for a special taskforce operating under the leadership of the Federal Office of Public Health. It was headed by its director, but a senior official called Daniel Koch, omnipresent at press conferences, soon became 'Mr Corona' and the public face of the federal pandemic strategy. In addition, an ad hoc taskforce was established with the mandate to coordinate action and support the Federal Council in its decision-making. In this body, all federal ministries and the army were represented to ensure horizontal policy coordination. The general secretary of the inter-cantonal conference of cantonal governments was also a member of this federal taskforce. The latter was supported by three affiliated ad hoc bodies, one representing the economy, one civil society, and a third, named the Swiss Covid-19 Science Task Force, academia. All of these bodies were rapidly set up to counter criticism that the Federal Council was neglecting the interests of private economic actors, failing to involve non-governmental organisations, and not being guided sufficiently by scientific evidence.

The burgeoning of emergency bodies can be taken as a sign that Switzerland's institutions were not ideally prepared to face a major crisis. The institutions provided for by law were centred on health issues and not up to the task of coordinating a comprehensive pandemic response. The cantonal and federal ad hoc taskforces suffered from other shortcomings. As they were not regulated by law, or regulated only by internal directives, their composition, competences, and procedures had to be contrived in a hurry. As for the supporting bodies that shot up out of the ground, it was unclear who had nominated whom and according to what criteria. Like the federal taskforce itself, they were composed predominantly of men, a reminder that, in the absence of rules, the old gentlemen's club inexorably takes over. On $8 \mathrm{March}$, women activists were demonstrating with placards that read, 'Not My Taskforce'.

\subsection{Rolling out measures to contain the pandemic}

Switzerland's pandemic response can be divided into three phases. The cantons were the first to act, but when the Federal Council declared an extraordinary situation, most powers shifted to the central level. Once the situation was downgraded to being special, the Confederation and cantons struggled to sort out their respective competences and coordinate their actions.

\subsubsection{Taking the initiative}

At the end of January 2020, the federal authorities established a special taskforce closely cooperating with the cantonal health authorities and immediately launching an information campaign about sanitary measures. Ticino and other southern cantons were soon expressing fears that the pandemic, then raging in Northern Italy, would cross the border and that federal measures were insufficient to contain it. However, their request that borders be closed was not taken 
up by the federal authorities. On 25 February, the Federal Office of Public Health confirmed the first Swiss Covid-19 case, in Ticino. The patient was put in an isolation unit, and all contact persons were notified and placed in quarantine by the cantonal health authorities.

As the coronavirus spread, the cantons started to prepare for an epidemic by establishing special task forces (Uri and Glarus), or setting up quarantine apartments (Bern). They traced infections and put hundreds of people in quarantine. Ticino was the first canton to issue preventative measures: it prohibited major events, such as popular carnival festivities, and banned spectators from hockey matches. At the outset, Ticino was hardest hit by the pandemic, with its health facilities conveying horrifying messages to the rest of the country. Later, the Lake Geneva region (Geneva, Vaud, and Valais) reached the highest numbers of cases and began to take measures. Other cantons, however, had not yet reported any cases.

After an extraordinary meeting on 28 February 2020, the Federal Council declared a 'special situation' under the federal Epidemics Act and immediately used its new powers to ban large-scale events involving more than a thousand people. The cantons enforced the federal ban and were allowed to issue stricter rules. Basel Stadt, Basel Landschaft, and Zug opted for a maximum of 200 persons at events and Aargau, for 150; other cantons obliged event organisers to give notifications of events or carry out risk assessments; and others yet adopted a wait-and-see approach. However, as the infection rate increased exponentially, the test-trace-contact-isolate strategy broke down in some cantons and health care systems began to reach capacity. By mid-March, it was clear that, left to their own devices, the cantons were unable to cope with the pandemic.

\subsubsection{Federal action}

On 13 March 2020, the Federal Council decided to issue stricter national rules. It imposed border controls on persons entering from Italy and closed all schools throughout Switzerland. It also banned events with more than a hundred participants, a rule which - after some hesitancy - also applied to ski resorts, thus abruptly ending the Swiss ski holiday season. In restaurants, bars, and discos, a maximum of 50 people was allowed. At the same time, the Federal Council made up to CHF 10 billion in emergency aid available to cushion the economic impact of the pandemic response. This aid was immediately available to enterprises, which could get government-backed loans from their banks within hours - the Federal Council insisted on prompt aid without bureaucratic hassles.

Only three days later, the Federal Council declared an 'extraordinary situation'. The next day, lockdown rules were issued. All public and private events were prohibited, and all but essential shops were closed, as were markets, restaurants, bars, and entertainment and leisure facilities. Only pharmacies, petrol and railway stations, banks, post offices, hotels, public administrations and social institutions, food stores, takeaway outlets, canteens, and food-delivery services 
stayed open. Hospitals, clinics, and medical practices had to forego non-urgent medical treatments. The Federal Council also authorised the deployment of up to 8,000 members of the armed forces to assist the cantons; introduced checks at the borders with Germany, Austria, and France; and imposed entry bans. Two days later, these rules were extended to Spain and all non-Schengen states, and visa processes were suspended. Again, two days later, on 20 March, the Federal Council issued a new series of measures. It banned gatherings of more than five people, prohibited the collection of signatures for popular initiatives and referenda, and issued a standstill on deadlines on the collection of signatures. It also approved an impressive additional aid package of CHF 32 billion, bringing the total economic relief measures up to $\mathrm{CHF} 40$ billion.

At the peak of the first wave of Covid-19 infections, the concentration of power in the hands of the Federal Council was extraordinary. The federal executive issued and amended one emergency ordinance after the other, with no obligation to consult Parliament or cantons. Only a few of these ordinances, such as the ones relating to border control or the deployment of the army, concerned matters that were typically federal competences - most of them, such as those to do with health, education, the economy, and cultural activity interfered in spheres normally governed by the cantons. The federal government actions reduced cantons to mere implementation agencies that were no longer allowed to decide on their own how to run their hospitals, schools, or other institutions.

Although this upscaling of competences is provided for by the Constitution and the Epidemics Act, its effect took many by surprise. The concentration of power occurred not only vertically but also horizontally; as a result, it was not the Confederation which was in charge, only its executive. In mid-March, when the Federal Assembly decided to suspend its sessions, the chambers of Parliament were deserted. The members of both chambers returned home to their domiciles and left the scene to the executive and its councillors (Caroni and Schmid 2020: 211-12). It became clear that Parliament was ill-prepared to operate during a health emergency. There were few rules on the involvement of parliamentary commissions in decision-making, and no preparedness for the legislature to function as an e-parliament.

In the cantons, the situation was equally concerning. With direct democratic mechanisms having been suspended, direct democracy in Switzerland was on hold as well. When some cantonal parliamentarians attempted to open their session, they were told by the federal authorities that their meeting fell under the prohibition of gatherings of more than five people (Bergamin and Mazidi 2020: N51-4; Uhlmann 2020: N5-16). Local assemblies, crucial actors in local self-administration, were similarly prevented from operating. Everyone, except the Federal Council and its administration, seemed to obey the stay-at-home recommendation.

Most actors, including the media, seemed to approve of this dominance by the Federal Council. However, as time went by, and as people recovered from the shock and learnt how to work effectively from home, the executive's extensive 
use of emergency powers became a subject of controversy. The effects of the lockdown measures on fundamental rights and freedoms, on the one hand, and the autonomy and participation rights of cantons, on the other hand, were enormous - and not all of the measures respected the principle of proportionality and subsidiarity (Belser et al. 2020: 5-7; Märkli 2020: 62-4). Some of the executive ordinances, for instance, were in conflict with federal parliamentary laws, while others, especially those relating to direct democratic rights, conflicted with the Federal Constitution (Biaggini 2020a: 254-6). The rule that signatures for a popular initiative must be collected within 18 months and for an optional referendum within 100 days are provided for by the Constitution itself. If the Federal Council could simply override these constitutional rights, what else could it do?

Given that direct democracy constitutes the main instrument of government accountability, its suspension raised fundamental questions about the control of power (Biaggini 2020b: 281-2). Aggrieved Swiss citizens typically collect signatures for referenda rather than applying to the courts. Notoriously, judicial review is limited: it applies fully to cantonal acts only and is limited when federal norms are at stake. As a rule, acts of the Federal Council may not be challenged in the Federal Supreme Court (Federal Constitution, article 189, paragraph 4). Thus, the judiciary has no mandate to review the declaration of special or extraordinary situations or emergency ordinances (Gerber 2020: N6-13; Märkli 2020: 62). When local, cantonal, and national populations and their representatives were silenced, scheduled referenda votes postponed, and the collection of signatures suspended, there was no one left to counterbalance the emergency powers of the Federal Council - and in such a situation, the limited powers of the federal judiciary seemed especially problematic.

The media customarily took it upon themselves to function as public watchdogs and urged federal civil servants to exercise their individual judgment rather than blindly follow orders from above. Nevertheless, the country was governed by central executive rule for three months in an unprecedented and largely uncontrolled way (Belser et al. 2020: 2-4). While it lasted, few actors seemed overly troubled, holding to the view instead that the exigencies of the pandemic necessitated fast and uniform action. The fact that there were few concerns about abuse of power was probably due to the generally high level of trust in institutions as well as the unique structure of the Federal Council.

In Switzerland, the concentration of power at the federal level does not mean that one strong individual takes over - it means seven take over. Uncompromising and polarising personalities are typically not elected members of the Federal Council, as they cannot succeed in a collegial body. In addition, all the linguistic groups of the country and all four major parties are represented, given that the government is elected by a 'magic formula' guaranteeing the inclusion of all relevant groups. During the emergency, the president of the Federal Council remained a prima inter pares member of a collegial body that continued to base its decisions on consensus. The composition of the Federal Council and its way of functioning thus served as an inbuilt check on power. The fact that the left-wing 
Social Democratic Party, the centrist Christian Democratic People's Party, the Liberals, and the right-wing Swiss People's Party all had one or two federal councillors represented contributed to making the executive orders acceptable to most.

Indeed, at press conferences, the Federal Council took care to speak in several languages and always be represented by more than one member. Attentive observers could tell that the Minister of Home Affairs and the President, both Social Democrats, would often have liked to issue stricter rules but that the Minister of Finance, a member of the People's Party, prevented this from happening (Neue Zürcher Zeitung 2020). The Federal Council hence seemed able to balance different interests, views, and priorities even in the absence of the usual checks and balances.

In April 2020, parliamentary commissions and chamber presidents resumed work, were consulted by the Federal Council, and made extensive use of parliamentary mechanisms to get involved in the decision-making processes (Caroni and Schmid 2020: 712). While the Federal Council continued to issue or amend dozens of emergency ordinances, the Federal Assembly reconvened in May for an extraordinary session dedicated to Covid-19, one it used mostly to endorse and widen the Federal Council's economic support programmes. During the regular session in June, Parliament approved the Federal Covid-19 Act, thereby creating a parliamentary basis for further economic support actions to be decided upon by the Federal Council. By delegating far-reaching spending powers to the executive, Parliament made it clear that it considered the Federal Council the most appropriate actor to manage the crisis.

Beginning in mid-April 2020, the Federal Council decided to ease its lockdown measures. At this point it started to dawn on observers that although the Swiss constitutional and statutory framework was rather well prepared for leading the country through a carefully managed emergency situation, it gave no clue about how to get out of it (Belser and Mazidi 2020). Who was to decide on the transition to a more normal situation, or to design, plan, and finance it? As there were no clear answers and pressures were mounting to get cantons back in control, the Federal Council decided on 19 June, when infection and hospitalisation rates had stabilised at a low level, that the situation was no longer extraordinary but special. Parliament was back in session, and cantons back in charge.

However, the rules applying to the special situation were unclear. While the Federal Council now insisted that cantons should act proactively, the same cantons asked the centre to take back control as soon as the weather cooled and case numbers rose. Precious time was lost in the summer months during which no one really seemed in control and official communication was scarce. While some cantons used the time in between the waves of infection to scale up their testing-and-tracing capacity, others hoped there simply would be no second wave - or that the Federal Council would again take over if they were wrong about this. When infection rates duly started to increase once more at the end of summer, the Federal Council agreed to issue an order for masks to be worn on public transport, as it seemed exceedingly impractical to expect train passengers 
to adjust their behaviour to the dictates of a new jurisdiction every time they crossed another cantonal border. For the rest, the Federal Council leaned back and bade the cantons to go forth and craft tailor-made responses of their own. While some did so, others did not.

By the end of October 2020, Switzerland was about to become Europe's latest Covid-19 hotspot. The second wave of infection hit it badly, yet both the national and cantonal tiers were hoping for the other to intervene and issue more restrictive measures. Mandatory masks seemed to be the only thing they could agree on - mostly because masks do not harm business and consequently provoke no demands for economic aid. On 28 October, the Federal Council decided on light and flexible lockdown rules, and - after much hesitation - provided CHF 30 million to cushion their economic effects. The cantons were asked to design their own rules and chip into the economic relief programmes. At the time of this writing, they were still pondering how far they should go.

\subsubsection{Cantonal action}

When the federal authorities took control of the pandemic response, the role of cantons was unclear. It was undisputed, even during the extraordinary situation, that it was up to them to implement the pandemic response. But could they issue their own emergency regulations? Could they be stricter, as the Canton of Ticino and most French-speaking cantons would have liked to be, or only more generous when it came to cushioning the economic shock? While this matter was being debated in scholarly commentary, the federal authorities expressed the view that the national-level pandemic response was exhaustive and did not allow cantons to go beyond it. The official argument was that diverse rules would lead to confusion, but the hidden concern was that cantons with stricter rules would ask for more financial support from the national emergency relief pot than others. Scholars argued in vain that cantons more adversely affected by the pandemic should be allowed to issue stricter rules - at least if they agreed to take responsibility for the economic effects of these rules (Belser et al. 2020: 4-7).

In order to resolve a serious conflict between the Federal Council and the Canton of Ticino, the Covid-19 ordinances opened so-called crisis windows allowing cantons to go beyond the national lockdown measures under defined circumstances, thereby retroactively legalising a cantonal ban on construction work (Bergamin and Mazidi 2020: N49-50; Bernard 2020: 63-4). The Lex Ticino, designed to accommodate an upset cantonal government, was removed as soon as the situation in the canton's hospitals improved. Disputes about the respective competences and financial responsibilities persisted, however, getting worse even as the curve flattened.

The non-application of the usual institutional mechanisms produced other hiccups. The insufficient involvement of cantons in the making of rules shaped some norms which the cantons found difficult to implement. After all, the federal health authorities were used to strategic planning and coordination only and 
lacked practical experience on the ground. When the Federal Council decided to ease measures and return from the extraordinary to the special situation, the country experienced an unprecedented, and disconcerting, struggle over competences and roles. The cantons had been asking for greater involvement, but the sudden retreat of the Federal Council caught them by surprise. 'Mr Corona' took his retirement and so, seemingly, did the federal government.

As it turned out, the cantons were not overly eager to take measures. It was politically unattractive to ban events or close institutions - and there was heavy economic pressure not to do so. Given the small size of most cantons, expected free-rider effects also severely reduced cantonal willingness to act. Why should Basel, Zurich, or Vaud ban events - and contend with requests for economic relief by the organisers - when their sports and cultural offerings attracted visitors from a large region? Why should national football games be allowed at some places and not in others? The federal authorities, however, did not share this interpretation of the principle of subsidiarity and continued to encourage the cantons to act - and to do so rapidly. Overall, the country seemed lost and its institutions incapable of taking timeous, appropriate action. It was then that journalists coined a new term for federalising, 'föderalen', meaning to shift responsibility to the cantons when it is inexpedient to act (Karpiczenko 2020).

It was only in October 2020, when the country was already badly hit by the second wave of Covid-19 that cantons started to issue stricter rules, to limit the operation of institutions, and to impose cantonal lockdown measures. While the Federal Council still urged the cantons to do more, it announced new national measures at the end of October. On 28 October, it amended the Covid-19 ordinance to prohibit discos and clubs, to require bars and restaurants to close at 11 $\mathrm{pm}$, to ban sporting and cultural events with more than 50 people, to expand the mandatory wearing of masks, and to oblige universities to suspend face-to-face teaching. With the exception of the increasingly active corona sceptics, most actors approved of the new national involvement, though while criticising the Federal Council for not simultaneously announcing an economic support programme.

\subsubsection{Local government action}

The role of local government in implementing pandemic control measures was crucial. Cities and villages were at the forefront of enforcing such measures. They adapted public buildings, in particular schools and health centres, to suit the new hygiene requirements, closed parks, removed benches, controlled events and enterprises, and enforced mask-wearing. At the same time, local governments did not issue their own pandemic responses, for instance by banning events or closing institutions on their own. The fact that this did not happen can probably be explained by the small size of most communes - Swiss territory is divided into 2,200 local governments, many of which have less than a thousand inhabitants. As for the large cities, they were able to voice their concerns within their respective cantons. 
To look beyond pandemic regulations, local governments were often highly innovative when challenged by the health crisis. They set up health and support teams, operated emergency lines, called households, offered help, and encouraged and coordinated neighbourhood support. Numerous municipalities also sought to complement federal and cantonal economic relief measures, including by supporting local enterprises with direct aid, such as encouraging consumers to buy locally and by issuing and subsidising coupons. Undoubtedly, local governments were in the best position to provide rapid aid to individuals and enterprises in difficult situations. As most of the municipalities are in charge of social assistance and thus of supporting those not aided by the federal social security system, they also had the greatest interest in timeously offering help and encouraging private support networks.

\subsubsection{Intergovernmental relations}

The participation of Swiss cantons in federal decision-making is generally strong. Cantons are represented in the second chamber of the Federal Assembly, and more importantly - have the right to participate in the federal decision-making process, in particular in the legislative process (Federal Constitution, article 45). In 2020, consultation and information-exchange between the Confederation and the cantons always took place, even during the extraordinary situation. However, in the early phase, cooperation was patchy. The representation of cantons in the Federal Council's ad hoc taskforce was clearly insufficient and a real coordination body lacking. The general secretary of the conference of cantonal governments had no mandate to speak on behalf of the cantons, which were affected differently by the pandemic and had differing views about the best way forward. He could play the role only of a transmission channel for information.

Over time, vertical cooperation improved. The return to the special situation made it clear that no federal measures were allowed to be taken without the involvement of the cantons. The experiences showed that this was not only a constitutional duty but a practical need. The federal administration was not well positioned to design effective measures in cantonal spheres of competences. It lacked data - a tremendous concern throughout the pandemic - and hands-on knowledge about testing capacities, information channels, and health and education structures. Strong cooperation also proved to be necessary in the field of federal competences. The decision of the Federal Council to close the border to Northern Italy threatened the health system in Ticino relying on thousands of health workers commuting daily, while controlling the border to France severely affected all economic sectors of Geneva and the functioning of the international organisations based in the canton.

As most cantons are unreasonably small in the context of an increasingly mobile population, horizontal cooperation is a crucial feature of Swiss federalism. Conferences of cantonal governments and conferences of ministers of police, health, and education coordinate and harmonise cantonal policies and 
laws and seek to ensure that the concerns of the cantons are heard in Bern (Belser 2020: 285 ff.). However, in February and March 2020, horizontal cooperation was largely dysfunctional. The members of cantonal governments were overwhelmed by the task of dealing with the health crisis and its effects in their cantons. Although informal talks were never suspended, it was only after a few months that the inter-cantonal conferences resumed operating in their usual manner and that the conference of health ministers and the affiliated association of cantonal officers of health raised their voices and coordinated their actions.

\subsubsection{Intergovernmental fiscal relations}

Switzerland's federalism is characterised by a high level of fiscal decentralisation. Cantons issue and implement their own norms - and pay for it - and are in charge of implementing federal laws - and pay for it as well. Local governments adopt their own rules and fulfil federal and cantonal tasks delegated to them. The delivery and financing of most public services is thus heavily devolved to the cantons and local governments. The important role of the cantons and communes is also reflected on the revenue side, as each tier of government raises taxes and fees and none is over-dependent on transfers and grants.

Intergovernmental fiscal relations are guided by the constitutional principle of fiscal equivalence, composed of two elements: on the one hand, the collective body that benefits from a public service bears the costs thereof; on the other hand, the collective body that bears the costs of a public service may decide on the nature of that service (Federal Constitution, article 43(a), paragraphs 3 and 4). Hence, fiscal equivalence ensures that those benefiting from, financing and deciding on the provision of public goods are the same. The system is complemented by a scheme of vertical as well as horizontal financial equalisation designed to reduce the differences in financial capacity among the cantons, guarantee all cantons a minimum level of financial resources, and compensate for excessive financial burdens due to geographical or socio-demographic factors (Federal Constitution, article 135, paragraph 2).

The pandemic deeply challenged these intergovernmental fiscal relations. All of a sudden, federal authorities took costly decisions for which the cantons and communes were not prepared. National hygiene and sanitary norms made the running of all institutions significantly more expensive. More importantly, there were controversies about the sharing of the costs of economic recovery. What also upset the cantons was the fact that the Federal Council obliged hospitals and other health services to abstain from all non-urgent treatments, even in cantons which at that time hardly had any Covid-19 cases. At a high cost, all cantonal health services thus prepared for Covid patients and, while waiting for the wave to hit the hospitals, ran out of work and income.

Intergovernmental fiscal relations probably explain most of the hiccups in the Swiss reaction to the pandemic. For several months, for instance, the testing strategy was debated. The cantons used very different strategies to test people 
and thus were more or less effective in applying the test-trace-quarantine-isolate strategies. Their point of view was that the federal tier would have to pay for extra costs when issuing a binding national test strategy. Worse, the transmission of data was disastrously dysfunctional. For a long time, no actor seemed able to come up with reliable information on tests, test results, the use of hospital beds and intensive care units, and fatalities. It was obvious that preparation and cooperation in this field were sorely needed and that the numerous taskforces were navigating in the dark. Improving the data situation was hindered by financial disputes: Who should be in charge of a reliable health data system and finance its speedy establishment? Although many actors expressed concern about data protection (Vokinger 2020: 420-2), the hidden concerns were of a financial nature.

When the Federal Council downgraded the situation from extraordinary to special and urged the cantons to take over, financial matters were crucial in preventing prompt pandemic responses. In fact, the Federal Council, which had adopted large financial-support packages and increased social payments, was eager to step back. The cantons, however, were not keen to ban events or issue lockdown rules, as those suffering from the effects would turn to them for relief. Even when infection rates started to increase rapidly in September 2020, cantons hesitated to act and hoped for the Federal Council to keep control. It was at this moment that federalism seemed to fail the country, by hindering timely and adequate responses to the health crisis. Both the federal and cantonal tiers were eyeing each other, hoping for the other to act - and take financial responsibility for these actions.

\subsection{Findings and policy implications}

In normal times, the limited role of the Confederation and the far-reaching autonomy of the cantons and the communes raise little interest. During the pandemic, though, federalism seemed to matter and hoary debates about the right balance between unity and diversity resurfaced. Should there be cantonal or national lockdowns? Should cantons be allowed to decide on their testing strategies and tracing approach? Should they be allowed to control their borders, or at least discourage their populations from travelling? Such debates had not been witnessed in the country for a very long time.

The Swiss system of power-dividing and power-sharing impacted strongly on the management of the coronavirus pandemic. While the federal system had been put in emergency mode with ease, the real issue seemed to have been about how to adapt the system to an ongoing and dynamic emergency. The first reaction, that of concentrating power at the centre, fortunately gave way to more nuanced views. After all, nationwide measures are rarely proportionate, and certainly not in pandemics - during 2020, they were not far-reaching enough for those regions severely hit by Covid-19, while going beyond the necessary in regions not yet or no longer experiencing peaks in case numbers. As far as they limit human rights, the constitutionality of national restrictive measures must 
be questioned. Limitations of the right to education and health, to family and private life, and to economic activity and free movement must be kept to what is strictly needed at a particular time and place. The full implementation of human rights thus mandates tailor-made pandemic responses, which can be orchestrated top-down, as they are in some unitary states, or designed bottom-up. The latter has the advantage of being more legitimate and effective than the former. Regional and local actors, familiar with governing their region and resourced to do so, are in a better position than others to judge the necessity of restrictive measures and to lift them as soon as possible.

Although democracy had been suspended for months, it was back in operation by October 2020. The Federal Assembly operated behind Perspex panes, and its commissions reclaimed their right to be informed and consulted by the government. Direct democracy was also back, and the new Covid-19 ordinance made it clear that event bans did not apply to cantonal parliaments and other political assemblies, including demonstrations, which could take place provided that protection plans were in place. The profound challenges to the institutional architecture of the country, however, are very likely to leave traces.

At the federal level, it seems crucial to establish emergency-proof checks and balances. Among the options under discussion is that the Federal Council should no longer be allowed to empower itself by declaring a situation extraordinary, or to disempower itself during an emergency; instead, a parliamentary commission should be involved (Stöckli 2020: 49; Stöckli et al. 2020). During a crisis, parliament should be involved permanently and prepared for such involvement, in particular by getting ready to operate as an e-parliament (Caroni and Schmid 2020: 719-20; Stöckli et al. 2020). It has also been debated whether the mandate of the Federal Supreme Court should be expanded to allow for the abstract review of federal emergency ordinances (Stöckli 2020: 46; Stöckli et al. 2020).

At the cantonal level, it is mostly inter-cantonal collaboration that raises questions. How crisis-resistant can a federal system be which relies so strongly on the horizontal cooperation of 26 autonomous actors? Is it possible to inform and consult all of them or to allow all of them to sit in a joint emergency body? While the current practice of including only one cantonal representative on the national taskforce seems clearly insufficient, opening up the body to 26 actors appears to be inappropriate. An improvement of the situation thus seems to require profound changes in the field of intergovernmental relations and, eventually, the transformation of inter-cantonal conferences into supra-cantonal bodies. If such a change were successful, a representative delegation of the cantons could sit in a joint body with federal delegates and share responsibility for the planning, design, and implementation of the management of pandemics. Such stronger coordination seems essential to ensure a prompt and coherent response, to prevent spillover effects and, just as importantly, jointly sort out financial matters. As the latter will have long-term effects on all tiers of government and affect their room for manoeuvre in the future, the current hide-and-seek under way at the 
time of this writing must give way to negotiated solutions. After all, 'let's talk' has always been the motto of Swiss federalism - the country's political actors should walk that talk, even if they are wearing masks and visors.

\section{Note}

1 The author wishes to express her gratitude to MLaw Simon Mazidi, research assistant and $\mathrm{PhD}$ student at the University of Fribourg, for his invaluable support in the preparation of this chapter.

\section{References}

Belser, Eva Maria. 2020. 'Heading Together: Intergovernmental Relations and Horizontal Law-Making by Swiss Cantons', in Alain-G. Gagnon and Johanne Poirier (eds), Canadian Federalism and Its Future: Actors and Institutions. Montreal and Kingston: McGill-Queen's University Press.

Belser, Eva Maria and Simon Mazidi. 2020. 'Does Swiss Federalism Need Oxygen Treatment after Being Hit by the Covid-19 Crisis?' UACES Territorial Politics Blog, 2 June, https://uacesterrpol.wordpress.com/2020/06/02/does-swiss-federalism-needoxygen-treatment-after-been-hit-by-the-covid-19-crisis/ (accessed on 11 October 2020).

Belser, Eva Maria, Bernhard Waldmann and Andreas Stöckli. 2020. 'Der schweizerische Föderalismus funktioniert auch im Krisenmodus', IFF Newsletter 2/2020 COVID-19, 7 April, https://www3.unifr.ch/federalism/de/assets/public/files/Newsletter/IFF/ Newsletter_COVID-19_Beitrag_Belser_Stoeckli_Waldmann.pdf (accessed on 11 November 2020).

Bergamin, Florian and Simon Mazidi. 2020. 'Kompetenzabgrenzung zwischen Bund und Kantonen bei der Bekämpfung von Epidemien: Erste Einschätzungen unter besonderer Berücksichtigung der COVID-19-Verordnungen', IFF Newsletter 2/2020 COVID-19, 7 April, https://www3.unifr.ch/federalism/de/assets/public/files/Newsletter/IFF/ Bergamin.Mazidi_Kompetenzabgrenzung\%20zwischen\%20Bund\%20und\%20Kantonen_ COVID-19.pdf (accessed on 11 October 2020).

Bernard, Frédéric. 2020. 'La répartition des compétences entre la Confédération et les cantons en situation de pandémie', Zeitschrift für Schweizerisches Recht Sondernummer 'Pandemie und Recht': 55-67.

Biaggini, Giovanni. 2017a. Kommentar zu Art. 184. BV Kommentar, Bundesverfassung der Schweizerischen Eidgenossenschaft, 2nd ed. Zurich: Orell Füssli Verlag AG.

Biaggini, Giovanni. 2017b. Kommentar zu Art. 185. BV Kommentar, Bundesverfassung der Schweizerischen Eidgenossenschaft, 2nd ed. Zurich: Orell Füssli Verlag AG.

Biaggini, Giovanni. 2020a. 'Notrecht in Zeiten des Coronavirus - Eine Kritik der jüngsten Praxis des Bundesrats zu Art', 185 Abs. 3 BV. ZBl 121: 239-67.

Biaggini, Giovanni. 2020b. 'Der coronavirusbedingte Fristenstillstand bei eidgenössischen Volksbegehren - eine Fallstudie zur Tragfähigkeit von Art,' 185 Abs. 3 BV. ZBl 121: 277-87.

Brunner, Florian, Martin Wilhelm and Felix Uhlmann. 2020. 'Das Coronavirus und die Grenzen des Notrechts, Überlegungen zu einer ausserordentlichen Lage', AJP (6): 685-701.

Caroni, Andreas and Stefan G. Schmid. 2020. 'Notstand im Bundeshaus, Die Rolle der Bundesversammlung in der (Corona-) Krise,' AJP (6): 710-21. 
Federal Statistical Office. 2020. 'Bevölkerung: Panorama', https://www.bfs.admin.ch/bfs/en/ home/statistics/catalogues-databases/publications.assetdetail.13695287.html (accessed on 11. November 2020).

Federal Statistical Office. n.d. 'Mortality, Causes of Death', https://www.bfs.admin.ch/bfs/ en/home/statistics/health/state-health/mortality-causes-death.html (accessed on at 11 November 2020).

Gerber, Kaspar. 2020. 'Rechtsschutz bei Massnahmen des Bundesrats zur Bekämpfung der Covid-19-Pandemie, Am Beispiel der Schliessung von öffentlichen Einrichtungen für das Publikum und der Schutzkonzepte', sui-generis: 249-64.

Karpiczenko, Patrick. 2020. 'Föderalen', NZZ am Sonntag, 14 November, [third image], https://nzzas.nzz.ch/magazin/bildstrecke/karpipedia-ueber-bros-renitente-jasserund-feigen-foederalismus-ld.1586933 (accessed on 27 November 2020).

Kley, Andreas. 2011. 'Die UBS Rettung im historischen Kontext des Notrechts', ZBl 130: 123-38.

Kley, Andreas. 2020. 'Ausserordentliche Situationen verlangen nach ausserordentlichen Lösungen. - Ein staatsrechtliches Lehrstück zu Art. 7 EpG und Art.' 185 Abs. 3 BV. ZBl 121: $268-76$.

Künzli, Jörg. 2015. 'Kommentar zu Art. 185', in Bernhard Waldmann, Eva Maria Belser and Astrid Epiney (eds), Bundesverfassung, Basler Kommentar. Basel: Helbing Lichtenhahn Verlag.

Märkli, Benjamin. 2020. 'Notrecht in der Anwendungsprobe - Grundlegendes am Beispiel der COVID-19-Verordnungen', Sicherheit \& Recht (2): 59-67.

Neue Zürcher Zeitung. 2020. 'Der Bundesrat im Krisenmodus: von General Berset bis zu Skeptiker Maurer - die Rollenverteilung im Kampf gegen das Virus', 1 April, https:// www.nzz.ch/schweiz/bundesrat-im-krisenmodus-von-general-berset-bis-zu-skeptikermaurer-die-rollenverteilung-in-der-coronakrise-ld.1549352 (accessed on 23 November 2020).

Saxer, Urs. 2014. 'Kommentar zu Art. 185', in Bernhard Ehrenzeller, Benjamin Schindler, Rainer J. Schweizer and Klaus A.Vallender (eds), Die schweizerische Bundesverfassung, St. Galler Kommentar, 3rd ed. Zurich, St. Gallen: Dike.

Stöckli, Andreas. 2020. 'Regierung und Parlament in Pandemiezeiten', Zeitschrift für Schweizerisches Recht Sondernummer 'Pandemie und Recht': 9-54.

Stöckli, Andreas, Eva Maria Belser and Bernhard Waldmann. 2020. 'Gewaltenteilung in Pandemiezeiten', Neue Zürcher Zeitung, 26. May 8.

Uhlmann, Felix. 2020. 'Kompetenzen des Kantonsrates unter dem Notverordnungsrecht (Coronavirus) und weitere Fragen. Kurzgutachten zuhanden Kantonsrat Zürich', 19 March, https://www.ius.uzh.ch/dam/jcr:cf4f83e9-4ef0-4e15-a1d6-ba6427184478/ WP\%20Kurzgutachten\%20vom\%2019.\%20M\%C3\%A4rz\%202020.pdf (accessed on 11 November 2020).

Vokinger, Kerstin Noëlle. 2020. 'Die digitale Bekämpfung von Covid-19 und die Rolle des Bundes (rates)', Schweizerische Juristen-Zeitung 116: 412-23.

Zeltner, Thomas. 2018. Zukünftiger Bedarf im Bereich Koordinierter Sanitätsdienst. Gutachten zuhanden desVorstehers des Eidgenössischen Departementes fürVerteidigung, Bevölkerungsschutz und Sport (VBS), 18 December, https://www.newsd.admin.ch/ newsd/message/attachments/59943.pdf (accessed on 11 October 2020). 